BLS 33, No 1 2007. DOI: http://dx.doi.org/10.3765/bls.v33i1.3528

(published by the Berkeley Linguistics Society and the Linguistic Society of

America)

\title{
The Proto-Uto-Aztecan Cultivation Hypothesis: New Linguistic Evidence
}

JANE H. HILL

University of Arizona

\section{Introduction}

The Uto-Aztecan (UA) language family extends from Idaho to El Salvador. Most scholars, following Fowler (1983), locate the Proto-Uto-Aztecan (PUA) homeland in the uplands of the Gila River drainage in Arizona, New Mexico, Chihuahua, and Sonora. Glottochronological estimates date this protocommunity to between 4800 (Hale 1958-59) and 6000 (Miller 1983) years ago. ${ }^{1}$ At this time period all people in this region were hunter-gatherers.

Archaeologist Peter Bellwood (1997) interrupted this consensus with an alternative hypothesis: that UA geographical distribution resulted from a 'Neolithic spread' of a community of 'first farmers', from a PUA homeland located in Mesoamerica, where maize cultivation dates to about 5600 years ago. At the same time, archaeologists learned that maize cultivation in the U.S. Southwest began much earlier than had been thought. Maize (which exists only as a cultivated plant) has now been radiocarbon dated to over 4,000 years ago in the Tucson Basin (Mabry and Thiel 2006), the Gila River drainage near Safford, Arizona (B. Huckell 2005, L. Huckell 2005), and in the Four Corners region by 3500 years ago (Wills 1995).

In Hill (2001), in support of Bellwood's hypothesis, I presented cognate sets and PUA reconstructions for a 'maize complex': the plant and its parts, its cultivation and cuisine. I proposed that a UA migration was a central mechanism in the spread of maize cultivation to the U.S. Southwest. This proposal remains controversial. Linguists have challenged the reconstruction (e.g., Campbell 2003). Some archaeologists doubt that migration was a major mechanism of cultural change in the Late Archaic in the U.S. Southwest (e.g., Wills 1995). Many specialists in the northern Uto-Aztecan peoples find extremely dubious the idea that these groups are former cultivators who abandoned maize cultivation in favor of hunting and gathering after their arrival in the Southwest.

\footnotetext{
${ }^{1}$ At the risk of scandal, I cite glottochronological estimates, which correspond surprisingly well with what we know of the archaeology. New dates on maize have resolved the conflict noted in Hill (2001).
} 
Some Mesoamericanists (again see Campbell 2003) reject the implication that 'Corachol-Aztecan' (Campbell and Langacker 1978) has deep roots in Mesoamerican prehistory rather than being recent in the region. However, my claims about PUA origins do not bear directly on the question of the origins of the Nahua, who have been argued to be a poor fit within the Mesoamerican linguistic area (Campbell, Kaufman and Smith-Stark 1986). While it would be parsimonious to think of the geographical distribution of the subgroups of Uto-Aztecan that we know from the early historic period as directly reflecting the dynamics of the initial dispersal more than 4,000 years ago, from then until 1521 is a very long time, permitting much reshuffling of peoples and new ethnogenesis. But new evidence is accumulating in support of the idea that Aztecan peoples are old in Mesoamerica. Dakin and Wichmann (2000) and Dakin (2004) have presented linguistic evidence for an Aztecan presence during the early stages of the emergence of Mesoamerican complex societies. Macri and Looper (2003), Macri (2000, 2005, 2006), and Grofe (2006) have identified new epigraphic evidence for involvement of Nahua speakers in the Mesoamerican areal system by the 5th century A.D. Genetic samples from Nahua speakers exhibit the same distribution of frequencies of mtDNA haplogroups as do other Mesoamerican peoples (Resendez and Kemp 2005), and recent work on ancient DNA from a pre-contact cemetery at Tlatelolco (Resendez and Kemp 2005) finds that Aztecs buried there are indistinguishable from other Mesoamerican populations. Recent research has identified Mesoamerican features in northern Uto-Aztecan languages. Montes de Oca (2001) has identified the presence of Mesoamerican-type difrasismos, ritual couplets, in Luiseño, and I have found examples in the other Takic languages. The SOV word order characteristic of Uto-Aztecan was thought by Campbell, Kaufman and Smith-Stark (1986) to be definitively non-Mesoamerican. However P'urhepecha, located in the northwestern region that I consider to be the probable homeland for PUA, is strongly post-positional and may have V-final word order (Villavicencio 2006). ${ }^{2}$ Furthermore, grammatical features in Classical Nahuatl (CN) such as V-initial order (Hill and Hill 2004), noun classifiers and body-part locatives suggest involvement in the Mesoamerican areal system. Cora tends to right-shift topics, yielding V-initial order (Vásquez Soto 2001). Further consideration of this important issue is beyond the scope of this paper, but these facts suggest that research into the Uto-Aztecan problem may permit us to contribute a more delicate historicization for the emergence of the various features of the Mesoamerican areal system.

The present paper summarizes the major results of my research since Hill (2001). These include new cognates in the northern languages for forms in the PUA maize lexicon, a set of possible loans between Proto-Northern Uto-Aztecan (PNUA) and Proto-Kiowa-Tanoan (PKT) suggesting the presence of maize cultivation in the PNUA community, and a few hints that some PUA maize

\footnotetext{
${ }^{2}$ In discussion of this paper, Roberto Zavala (personal communication Feb. 9, 2007) pointed out that Mixe-Zoquean languages are largely verb-final. Among the Mesoamerican language families, Otomanguean, Mayan, and Totonacan are all strongly verb-initial.
} 


\section{The Proto-Uto-Aztecan Cultivation Hypothesis}

vocabulary may originate in Otomanguean languages, linking PUA more firmly to a Mesoamerican homeland.

\section{New Maize Vocabulary in the Northern Languages}

In Hill (2001) my reconstructions of maize vocabulary to a PUA stage depended almost entirely on Hopi. This left open the possibility that maize vocabulary represented a very early diffusion of maize lexicon into Hopi, rather than descent in Hopi from the PUA ancestral vocabulary. Hill (2001) included no cognates for any of the Takic languages. I have now identified what I believe to be two likely, and one possible, Takic reflexes in the PUA maize vocabulary. I have also identified a new item in Tübatulabal. These are seen in (1-9) below, which amends the cognate sets in Hill (2001). ${ }^{3}$

The first new item is Gabrielino șon-á:xe-y 'tortilla' in (1), from J. P. Harrington's field notes. Gabrielino $o$ and $u$ are not distinguished in unstressed syllables, so the form could be a reflex of set (2); set (1) seems a more likely source since reflexes in set (2) refer to non-edible (but see note 9) parts of the maize plant. I also suggest the possibility of the Kitanemuk form -huka? 'corn cob, corn stalk' in (1); it lacks the nasal, but a word in the maize domain with initial $h u$, from PUA * su by regular sound change in this language, looks suspicious. The second element of the Kitanemuk form may be a reflex of the PUA 'dry' word *ka-, also seen in Hopi qa:? $\ddot{o}$ 'dry ear of corn' in set (5). Tübatulabal paca:h- apaca:h 'to shell it', paca:hil 'shelled pine nuts' (from Voegelin 1958) in (3) adds a second Northern Uto-Aztecan (NUA) cognate for this set. I believe that the semantic shift is from the 'maize' domain to the 'pine-nut' domain, and not vice versa; this is argued in more detail (for Hopi qa:?ö 'dry ear of corn, pine cone') in Hill (2003). In set (3), I cite for the first time a usage in Classical Nahuatl from Sahagún (1981:64) where CN a:č-, usually 'seed' in general, distinguished from $\lambda a 0: 11 i$ 'corn kernels after shelling', clearly refers to the corn kernel, and does so in a piece of ritual language that may very well attest to archaic usage. This constitutes a partial reply to the challenge of Campbell (2003 and personal communications) that the word in (3) does not attest to PUA cultivation, but to a shift of meaning to 'corn kernel' at some post-PUA stage in some languages. The form is now attested in the meaning 'corn kernel' in Nahuatl, Cora, Yaqui, and Hopi, making a post-PUA semantic change less likely. In (4), Luiseño sá:xi-š 'wheat', from Elliott (1999), is a more convincing northern-language cognate for this set than is Tübatulabal a:-sagi: 'to roast', hitherto the only NUA reflex. In (5) I have added a new Numic resemblant form, Comanche hani woPora 'corncob' (Robinson and Armagost 1990). ${ }^{4}$ Item (6), PUA ${ }^{* *}$ sura 'embryo of corn, tender ear of green

\footnotetext{
${ }^{3}$ I give here only the sets that I have recently amended and/or corrected, or that must be mentioned in connection with arguments in this paper. Complete sets and references for the reflexes that are not new to this paper can be found in Hill (2001).

${ }^{4}$ The Comanche word hani means 'corn'; it is probably the same word as Hopi ha:ni 'corn flour, ground fine', and is, I suspect, a cognate rather than a loan. See example (10).
} 
Jane H. Hill

maize', is recently identified by Manaster Ramer (2000). I also note a few corrections from the 2001 data; these are bolded, as are the other new materials.

(1) *sunu 'corn ear, maize': PTP *hu:nu-i, EU sunú-t, GU sunú, TA sunú, MA súnnu 'cornfield', NA sin- $\lambda i /{ }^{*}$ sen- $\lambda i$; PNUA *supu : [HO sonowi 'sand grass (Calamovilfa gigantea)'], GA șon-á:xe-y 'tortilla' (literally, 'corn-put.in.mouth-non.possessed.noun.suffix'), KI -huka? 'corn cob, corn stalk' $(?)^{5}$

(2) *sono 'maize byproducts such as cobs, leaves, cane': EU sonó 'corn leaf', PTC *sono 'corn element' (TA sonó 'corn stubble', GU sonó 'corn stubble', sonógola 'corn crib'), TU [sonó 'cane'], sonovoLi-t 'straw storage bin', but hona-Li-t 'corn stubble'; PNUA *sono 'grass, tinder/hay, corn cob': [Mono sona 'hay' (Fowler 1972:326 comments 'may be borrowing'); Tümpisa Shoshone soni ' grass' (archaic); Owyhee Shoshone soni-pi 'grass', soni-pi 'rye grass' (Fowler 1972:83); CO soni 'grass'; Southern Paiute šoni 'tinder'], HO sö:yö ‘corn cob'

(3) *pa?ci 'corn ear, corn kernel, seed': PTC *paci 'seed, green corn ear' (YA baci, MA bácia 'seed', [GU pahcí'seed (but not of corn)]), CR hací 'green corn ear', [NA a:č- $\lambda i$ 'seed'], but note $\mathrm{CN}$ šin-a:č-iwa 'to plant corn seeds taken from images of the maize gods'; PNUA *pa:ca: HO pa:cama 'hominy', [TB paca:h- apaca:h 'to shell it', paca:hil 'shelled pine nuts']

(4) *saki 'popcorn, parched corn, to make parched corn or popcorn': PTP *ha:ki 'parched grain', EU sakit 'parched corn, esquite', PTC *saki-/saki 'to toast, parch' (GU sagilá 'comal', MA sá:ki 'esquite'), CR šahčéh 'popcorn', HU sak(:)kí 'esquite', Aztecan *saki/i 'parched corn, esquite'; Luiseño șá:xi-š ‘wheat', [TB a:-sagi: 'to roast']

*o?ra/*o?ri 'ear of corn, cob': TA o?na/ko?ná 'corncob', GU wohna 'corncob'; NA o:lo:- $\lambda$ 'corncob'; [Kawaiisu ono-ci 'hooked stick used to pull down pinyon cones', Tümpisha Shoshoni onno-cci 'pine cone harvesting hook'], CO hani wo?ora 'corncob'; HO qa:P̈̈ 'dried ear of corn', ö:vi(-Pat) 'butt end of the corn cob, proximal end of cob' (probably from $\ddot{o}$ : 'cob' + with combining form - vi from pi:h $\dot{f}$ 'breast, teat'). (Here, the common element may be *o?-, possibly in the word for 'bone'; HO lacks the thematic element $-r a / i$ so is not strictly speaking cognate; the interest

\footnotetext{
${ }^{5}$ Key to abbreviations not defined in text: CO Comanche, CR Cora, EU Eudeve, GA Gabrielino, GU Guarijio, HO Hopi, HU Huichol, KT Kiowa-Tanoan, MA Mayo, NA Nahuatl, PTC ProtoTaracahitic, PTP Proto-Tepiman, TA Tarahumara, TU Tubar, YA Yaqui. Forms in square brackets are cognate but not semantically within the maize complex.
} 


\section{The Proto-Uto-Aztecan Cultivation Hypothesis}

lies in the common formative element, compounded in $\mathrm{HO}$ with qa:-, probably 'dry'.)

(6) *sura 'embryo of corn, tender ear of green maize': EU surát 'kernel, seed'; NA ši:lo: $-\lambda$ 'tender ear of green maize before it solidifies'; HO soona(?at) 'kernel, edible part of any seed, meat of pinyon nut, embryo of corn, the nutriment of a plant as contrasted with its form' (probably PUA **sura 'heart', attested throughout the family, but shifted to the maize domain at the PUA stage in several languages)

(7) *ku:mi/u 'to nibble small pieces of food, especially corn on the cob or popcorn': TO ku:m 'to eat, chew on something that comes in little pieces', ku:mi-kuḍ 'corncob'; GU ku?mi-ná/-má 'to chew on something small and hard like parched corn', TA gumí 'to eat something in little bites, like parched corn or corn on the cob', MA kú:me 'to chew', CR má-h-ki-Pima-ka 'they eat it', HU ki-mé 'to chew little bites', [NA kimič-in 'mouse']; PNUA *kuma 'corn': Southern Paiute qumia 'old Indian name for corn, rarely used now'; San Juan Paiute kumwi 'Zea mays', kumut 'Amaranthus caudatus'; Southern Ute kim'y 'corn'; Kaibab Paiute kó-mi 'corn', Ute ku-mi-up 'corn', ku-ma 'corn', kūm-wi 'seed of corn', kumu1-i-vai-a 'corn cob'; CO kukịme-pị 'parched corn, toasted maize'; HO kokoma 'dark red, almost purple corn', [komo 'Amaranthus cruentus' (a dye plant)]

(8) *wika 'digging stick': PTP *gi:kai 'dibble stick, plow', PTC *wika 'coa', HU wiká/wi:.ká 'pichueca'; HO wì:k'a 'digging stick'; TB wi:ginat/ Piwi:gin 'to stir', given in Hill (2001) may be related not to this word, but to the California word *wi:wi- 'acorn gruel'

(9) *Pica 'to plant': PTP *?isa 'to plant'; PTC *e:ca 'to plant', HU Pe- 'to plant placing seeds in the earth', (NA e- $\lambda$ 'bean' (??)); PNUA *iya 'to plant': Northern Paiute iappi, Shoshone iPapi 'Chenopodium spp.' (Fowler 1972:188), Tümpisa Shoshone iah 'to plant', Kawaiisu Pł?a 'to plant', Southern Paiute ia 'to plant', Ute Piáy 'to plant', HO i:ya 'to plant'. Northern Paiute masia 'plant', given in Hill (2001) is not related to this set.

\section{Indirect Evidence for PNUA Cultivation}

Many anthropologists consider that the abandonment of cultivation in favor of hunting and gathering as a subsistence strategy is very rare and unusual, thus throwing into doubt the proposal that the PNUA community included maize cultivators. In Hill (2003) I pointed out that cultivation is attested from the earliest historic period for several NUA groups, including the Owens Valley Paiute, the Agua Caliente Cahuilla, the Shoshone at Walker River, and for Southern Numic 
Jane H. Hill

groups throughout their distribution from the Chemehuevi in the west to several Ute bands in the east. While this cultivation may result from diffusion from Yuman cultivators along the Colorado River (for the Cahuilla and Chemehuevi) and from the Hopi (for the Southern Paiute and Ute), there is some linguistic evidence for the alternative hypothesis, that these cultivation complexes trace to cultivation among the PNUA.

First is a pair of words shared by Hopi and Comanche. The Comanche, a Central Numic group, were on the Great Plains by the historic period. While they were primarily buffalo hunters, they may have done some cultivation, and they traded for maize with cultivators. Their maize vocabulary shares at least two words, not with the Tanoan and Keresan peoples of the upper Rio Grande who were their raiding victims and trading partners, but with Hopi, two hundred miles to the west. While the Comanche did not raid as far west as Hopi, an anonymous referee for Hill (2007) pointed out that Ute bands did raid Hopi and were in contact with the Comanche, so that Hopi words might have reached Comanche by way of the Utes. However, the words in (10) and (11) are not found in the attested lexicon of Southern Ute (either in Givón (1979) or Charney (1996)). Thus the possibility remains open that they represent a residue of a common NUA maize vocabulary that does not survive in the attested lexicons of other NUA languages. The Hopi form ho:ma 'ceremonial cornmeal' is, I believe, a reflex of PUA *u:ma, seen also in Nahuatl $i: m a-$, an element that appears in a number of words having to do with 'respect, prudence, seriousness, fear' ${ }^{6}$

(10) HO ha:ni 'corn flour ground fine'; CO haniíbi 'maize' (with combining form hani- in many compound expressions)

HO ho:ma 'ceremonial cornmeal'; CO homopi 'powder, flour'

The second set of evidence is the presence of a series of resemblances between PNUA and PKT. Whorf and Trager (1937) and Davis (1989), used some of these to argue for a common ancestor of the two groups, 'Proto-Azteco-Tanoan.' However, a claim that this ancestor included words for maize is obviously anachronistic. Instead, these resemblances may date to an exchange of vocabulary that took place in the Four Corners region of the Colorado Plateau about 3500 years ago, originally identified by archaeologist R. G. Matson. Matson (1991) proposed that the Western Basketmaker II (WBM II), immigrant cultivators on the Colorado Plateau in the second millennium B.C., with many connections to the south, were probably Uto-Aztecans. The Eastern Basketmaker II (EBM II), huntergatherers located as far west as the Four Corners region, exhibit continuities from the Archaic period on the Colorado Plateau. This external evidence suggests a context of immigrant cultivators new to the Colorado Plateau, struggling to

\footnotetext{
${ }^{6}$ Also of great interest is Luiseño humáhma-š 'worthless, nothing, nonsense, bogus, invalid, ridiculous, absurd, wrong' - a semantic reversal from the Hopi and Nahuatl meanings of 'sacred, prudent', etc.
} 


\section{The Proto-Uto-Aztecan Cultivation Hypothesis}

survive there, obtaining information about local flora and fauna from indigenous hunter-gatherers, and in turn sharing their knowledge of maize cultivation. Although initially only the WBM II groups cultivated maize, by about 2500 years ago the EBM II cultivate also. The linguistic evidence for this exchange, ${ }^{7}$ summarized in (12-15) and (16-24), is discussed in detail in Hill (2007) and complete argumentation and sources can be found there.

The first set of items, that I believe were loaned from PNUA into PKT, are shown in (12-15). I give the KT reflexes; the NUA reflexes can be found in (1-9) above. For the KT forms, where Whorf and Trager (1937) or Davis (1989) give reconstructions, these are listed, but I also give reconstructions following the proposals by Hale $(1962,1967)$ where there is enough KT material, in my view, to take this step. In these examples, if Hale actually proposed a reconstruction, this is given with a full citation.

(12) PNUA *iya 'to plant' (see example (9)); PKT *?ia 'corn' (Davis 1989:363); ${ }^{*} V_{8}$ in Hale's system): Northern Tiwa ?ia and Southern Tiwa Pie; cf. Taos Ria-Pane 'corn' (from Pia-Pia-ne, where -ne is a noun class suffix), Southern Tiwa ie-mapa-ru 'corn-ear.of.corn-noun.class, cottonwrapped corn ear bundle', ie-tainin 'corn people'; Kiowa ?é: 'corn', e.g., (a) Ré: 'duoplural' of the following two forms, ?é:-gó 'fruit, seed' (singular) and ?é:-bó 'fruit, vegetable, edible seed, loaf of bread, bread' (with variant inverse suffix); (b) Ré:-tháttò 'grain of corn' (singular), Pé:- $t^{h}$ âl 'grain of corn, ear of corn, plant of corn' (duoplural); (c) Ré:-góp 'corn plant, corn stalk'; (d) Ré:-k'óp 'to plant'

(13) PNUA *kuma 'corn' (see example (7)); PKT * $k^{h}$ o (Whorf \& Trager 1937:621, No. 21), ${ }^{*} k^{h} u,{ }^{*} k^{h}$ a 'corn, seed' (Davis 1989:370): Arizona Tewa (AZT) $k^{h} u l u \eta$ 'corn', ${ }^{8}$ Rio Grande Tewa (RGT) $k^{h} u(\eta)$ 'corn, corncob'; Taos xə (W\&T 1937:621, given without gloss); Picuris xə?ene 'seed'; RGT $k^{h} e$ 'grains'; AZT $k^{h}$ ili 'grain, corn grain'

(14) PNUA *pa?ca 'corn kernel, hominy' (see example (3)); PKT *p'əa 'fresh corn' (Davis 1989:369); * ${ }^{\prime} V_{5}$ in Hale's system: Taos (Northern Tiwa) $p$ 'ia 'corn'; Picuris (Northern Tiwa) p'ù- 'corn in field'; Isleta (Southern Tiwa) $p$ ”a 'fresh corn', $p$ ’' 'green corn (on cob)'; Jemez p'ò: 'green corn, corn on cob'; RGT p'è: 'fresh corn'; Kiowa p’ó:gyá 'young, immature, green'

\footnotetext{
${ }^{7}$ I thank Laurel Watkins for checking the KT materials and for providing lexical material from her own collections and from handwritten notes developed by Ken Hale.

${ }^{8}$ The incremented $-l V$ - in AZT is a regular feature of this language (see correspondence sets in Kroskrity 1993:229-236)
} 
PNUA *sono 'corn by-products' (see example (2)); PKT * ${ } V$ 'grass, grass seed' (in Hale's system): Taos (p'òn)- $t i$ 'pasture grass'; Isleta $t i$ 'grass, hay', $t i$-(ta) 'wheat'; Jemez $t_{1}^{y}$ : ' grass'; Kiowa són 'grass' 9

In PKT, the items in (12-15) are all very short words - in fact, on the Hale reconstruction the only genuinely reconstructed element is the initial consonant. On this evidence alone, we should perhaps attribute these resemblances to chance. ${ }^{10}$ However, the case for identifying these as loans from PNUA is enhanced by another set of resemblances between PKT and PNUA in words for important economic plants and game animals of the Colorado Plateau. These words are all restricted to NUA within UA. Examples (19) and (21) have possible morphological analyses in KT, but not in NUA, suggesting that if these are loans, they are from PKT into PNUA. The plants are all either restricted to, or much more widely distributed and important on, the Colorado Plateau as compared to the deserts to the south. These novel economic plants would be crucial to the survival of immigrant cultivators in a context where their maize yields were probably drastically reduced compared to those they had achieved at lower altitudes.

(16) PNUA *tipat 'pinyon pine, pinyon nut'; PKT *t'ou (Davis 1989:370), ${ }^{*} t$ ' $V_{2}$ in Hale's system

(18) PNUA *si:wi 'Wild onion'; PKT ${ }^{*} V_{9}(w V)$ in Hale's system: Taos Híw-; Isleta fiw, RGT si 'wild onion, onion', AZT si?u 'Allium recurvatum, wild onion' ; Jemez t'íwé 'onion'; Kiowa sôl (singular), sô:tò (inverse) 'wild onion'

(19) PNUA *yampa 'Carum gairdneri'; RGT nam- $p^{h} u$ 'earth-swelling, potato' where Tewa nam 'earth' < PKT *dam

(20) PNUA *siko 'Calochortus spp., sego lily'; RGT sægobe 'domestic potato, white-flowered plant with small edible tubers'

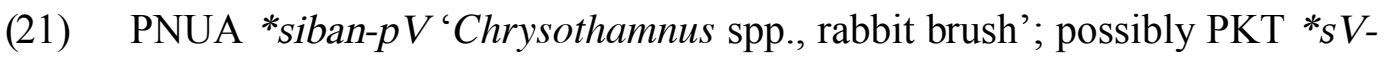
$p^{h} V_{3}-p^{h} V^{\prime}$ rain-cloud-Chrysothamnus, rain-cloud-plant'

\footnotetext{
${ }^{9}$ The loan of this word may reflect the use of the sweet stalks of corn as a food source, which Smalley and Blake (2003) have suggested may have been important in the early history of maize domestication.

${ }^{10}$ Although these resemblances would constitute a fairly high percentage of reconstructible maize vocabulary, which for the major Mesoamerican languages ranges from 11 (for Otomanguean) to 17 (for Mayan), with 12 for Uto-Aztecan and 13 for Mixe-Zoquean (Hill 2006)
} 


\section{The Proto-Uto-Aztecan Cultivation Hypothesis}

PNUA *tihi- 'deer'; PKT *tə ‘elk' (Davis 1989:369), *t $V_{3}$ 'elk' in Hale’s system

PNUA *tihin $V$ - 'pronghorn'; PKT *t' $V_{2}$ 'pronghorn' $\left(\right.$ Hale 1962, 1967) ${ }^{11}$

PNUA *pa:Pa-ta 'mountain sheep'; PKT *pę 'deer' (Davis 1989:368), ${ }^{*} p V_{3}$ in Hale's system

\section{The Otomanguean Connection}

Some of the PUA maize vocabulary listed in (1-9) may be borrowed from Western Otomanguean, at a stage no later than Proto-Oto-Chinantecan (POCh). Kaufman's (1990) breakup date for Western Otomanguean, 4500 years ago, is close to Hale's (1958-59) oldest UA separation date of 4733. Kaufman locates POCh in the highlands of west-central Mexico, in a crescent from Morelos through Toluca to Querétaro. This is an excellent candidate region for the location of PUA, which I have already proposed originated in northwest Mesoamerica. This region is largely pine-forested highlands, with the same flora and fauna, at the generic level, that Fowler (1983) reconstructed for a PUA homeland in the Gila River uplands.

Campbell (1979:949) suggested that Uto-Aztecan **sunu 'corn' is 'almost certainly a loan from Otomanguean.' Such a loan must be into PUA, since, as shown in (1) above, ${ }^{* *}$ sunu reconstructs to the protolanguage. Campbell's source is the Proto-Otomanguean (POM) form seen in (25), as reconstructed by Rensch and Kaufman. ${ }^{12}$

a. **se(n) (Rensch 1976, \#285) 'ear of corn, corncob, masa, corn flour'

b. **sa(aP)ai(n) 'ear of corn' (Kaufman 1990)

Additional similarities between Otomanguean and PUA can be identified. Taube (2000) observed a set of iconographic connections linking maize to two of the most important Mesoamerican prestige goods, greenstone and iridescent green quetzal feathers. An obvious metaphoric link between maize, jadeite, and quetzal feathers is the color green. Within both PUA and POM, the words for 'corn' and 'green' as well as green things like grass, leaves, and willow trees, resemble one another. This is seen in (26) and (27). Furthermore, we can see that across the two families, the words are also resemblant. There is no linguistic evidence of this kind of metaphoric link except in Uto-Aztecan and Otomanguean. In the other Mesoamerican families, both present-day and proto-language words for 'corn' and 'green/grass/leaf/etc.' are entirely distinct.

\footnotetext{
11 'Pronghorn' and 'deer' may be related words; however the full cognate sets look quite different from one another (see Hill 2007).

${ }^{12}$ Rensch gives no POM glosses; the glosses given here are drawn from the meanings that Rensch gives for cognates in the daughter languages.
} 
Jane H. Hill

(26) PUA words for 'corn' and 'green'

a. **sunu 'corn ear, maize'; **suu- : NA šiwi- 'green, jade, turquoise'

b. ${ }^{* *}$ sono 'maize byproducts such as cobs, leaves, cane'; ${ }^{* *}$ So- : in 'grass' throughout family; NA soso:wik 'something green, raw'

c. *saki 'parched corn, popcorn'; **sa-: PNUA *sakwa 'green, glue, color of turquoise', PUA **sawa 'leaf'; PUA **saka 'willow, grass'

(27) POM words for 'corn' and 'green'

a. **se(n) (Rensch 1976, \#285) 'ear of corn, corncob, masa, corn flour'; ** $\operatorname{se}(n)^{1 / 2}$ ' grass, hay' (Rensch 1976, \#272)

b. **sa(a )ai(n) 'ear of corn' (Kaufman 1990); **sa(n) 'green, raw' (Rensch 1976, \#303); **(n)sa 'green' (Kaufman 1990) (Suárez (1980:59) reconstructs ${ }^{* *} Y$ sa)

So far I have shown only corn words with initial ${ }^{*} s$ in PUA and POM. However, in both proto-languages, alongside the words for 'corn' and 'green' with initial *s, there are also words for 'corn' and 'green' with initial ${ }^{*} k^{w}$ or ${ }^{*} k u$ (simply ${ }^{*} k$ in the Uto-Aztecan form for 'green'). These are seen in (28) and (29).

(28) PUA words for 'corn' and 'green' in initial ${ }^{*} k u,{ }^{*} k: * * k u: m i / u$ 'to eat food that comes in little pieces, especially corn and popcorn; corn' (in PNUA only); *kan- 'willow' (PNUA only): Numic *kahna-, HO qahavi, Tübatulabal ha:-l, Cahuilla qá:nki-š

(29) POM words for 'corn' and 'green' in initial ${ }^{*} k^{w}:{ }^{*} k^{w} e$ 'corn, ear of corn, masa, atole, corn kernels' (Rensch 1976, \#177), ** ${ }^{*}{ }^{w} a u$ 'corn' (Kaufman 1990); ** $k^{w} e$ 'green, blue, raw' (Rensch 1976, \#174) / **w(y)e7 'green, blue' (Kaufman 1990) (but note Proto-Popoloca *šę $\sim$ kwhę7; ProtoOtopame *poe-th in support of Rensch's initial stop); POM * $k^{w a}$ 'bush, leaf, forage, etc.'

If these resemblances are the result of contact, the initial consonant alternation ${ }^{*} S \sim{ }^{*} k^{w}$ locates their origin in Otomanguean, where such alternations among initial consonants are broadly productive throughout the lexicon for ProtoOtomanguean and several subfamilies (Bartholemew 1965, Gudschinsky 1959, Longacre 1957, Rensch 1976, Suárez 1980). Rensch (1976:31-34) proposed six sets of consonant alternations for Proto-Otomanguean; of interest here is ${ }^{*} k^{w} \sim{ }^{*} y$ $\sim{ }^{*}$ S. The Otomanguean 'corn/green' words do not have any examples of initial ${ }^{*} y$, but they attest ${ }^{*} k^{w} \sim *^{*} s$ in pairs like ${ }^{*} \operatorname{se}(n) \sim{ }^{*} k^{w} \mathrm{e}$ 'corn' and ${ }^{*} s a(n)$ 'green' $\sim{ }^{*} k^{w} a$ 'bush, leaf, forage, etc.' seen in (27) and (29). Among the various Otomanguean consonant alternations, the ${ }^{*} k^{w} \sim{ }^{*} S$ alternation does not reconstruct for the ancestor of Oto-Pamean, the most northerly subgroup within Otomanguean. Chinantecan does preserve the relevant etyma with reflexes of initial ${ }^{*} k^{w}$ 


\section{The Proto-Uto-Aztecan Cultivation Hypothesis}

(Kaufman 1990:103) and shows the ${ }^{*} k^{w} \sim{ }^{*}$ alternation (Rensch 1976:335 (n. 14)). Thus, if PUA words with alternating ${ }^{*} S$ and ${ }^{*} k$ are in fact borrowed from Otomanguean, this borrowing could not date later than the POCh stage, and would place PUA well within the boundaries of Mesoamerica, no further north than approximately Queretaro, ruling out a northern homeland.

\section{Conclusion}

Linguistic evidence for the Mesoamerican cultivator origin of the UA peoples is not yet decisive. Questions remain about the details of phonological reconstruction of several items in the maize vocabulary, and better attestation of maize vocabulary in the northern languages is needed. Campbell (2003) suggests that parallel semantic changes - grass $>$ corn, seed in general $>$ corn seed, grass as building material and tinder $>$ non-edible parts of maize plant, seed cake $>$ corn cake - could have moved all of these items into the maize domain independently in many Uto-Aztecan languages after the breakup of the proto-language, as maize cultivation diffused through UA communities. Many conundrums remain for the PNUA-PKT connection, quite apart from the problems reconstructing PKT. For instance, PNUA exhibits *?o:- 'mesquite', attested in all NUA groups except Hopi. 3500 years ago mesquites were probably not found on the Colorado Plateau east of the headwaters of the Virgin River (although they are found immediately south of the Rim in the drainages of the Verde and Salt Rivers), so the reconstruction of this word challenges the Four Corners location for PNUA suggested in Section 2. While the complex interlocking resemblances between Proto-Otomanguean and PUA maize/green words are suggestive, it remains possible that these are the result of coincidence, so it is important to find more resemblant forms attesting to the hypothesized episode of contact. Contributions and critique from experts on Otomanguean will be required to advance this line of research.

While the linguistic evidence has many problems and weaknesses, it is consistent with recent findings in archaeology and epigraphy. The appearance of maize in the U.S. Southwest only 1500 years after it is first identified in southern Mexico, and the cultural discontinuity between late-archaic hunter-gatherers and late-archaic cultivators in the Southwest, is consistent with a migration. UtoAztecans are the most obvious candidates for the agents of such a process. While the evidence from human genetics (e.g., Smith et al. 2000, Kemp 2006) is far from definitive, it does not contradict the hypotheses suggested here. Furthermore, linguistic and epigraphic evidence is accumulating for the antiquity of a Uto-Aztecan presence within Mesoamerica.

In spite of the many unanswered questions, the evidence identified thus far suggests that the hypothesis of Uto-Aztecan origins and prehistory is worth pursuing. By relocating the probable PUA homeland, the hypothesis especially invites the involvement of specialists in Mexican languages. Uto-Aztecan, rather than being a marginal latecomer to the linguistic prehistory of Mesoamerica, might turn out to be absolutely central to it, requiring us to rethink many longestablished ideas about Mesoamerican linguistic and cultural dynamics. However 
Jane H. Hill

all this turns out, continuing to test these ideas should at the very least help us refine our understanding of this ancient and endlessly fascinating context.

\section{References}

Bartholomew, Doris. 1965. The Reconstruction of Otopamean (Mexico). University of Chicago Ph.D. Dissertation (cited in Rensch 1976).

Bellwood, Peter. 1997 Prehistoric Cultural Explanations for Widespread Linguistic Families. In P. McConvell and N. Evans, eds., Archaeology and Linguistics: Aboriginal Australia in Global Perspective, 123-134. Melbourne: Oxford University Press.

Campbell, Lyle. 1979. Middle American Languages. In L. Campbell and M. Mithun, eds., The Languages of Native America: Historical and Compatative Assessment, 902-1000. Austin and London: University of Texas Press.

Campbell, Lyle. 2003. What Drives Linguistic Diversification and Language Spread? In P. Bellwood and C. Renfrew (eds.), Examining the Farming/Language Dispersal Hypothesis, 49-64. Cambridge: McDonald Institute for Archaeological Research.

Campbell, Lyle, Terrence Kaufman, and Thomas C. Smith-Stark. 1986. MesoAmerica as a Linguistic Area. Language 62:530-570.

Campbell, Lyle and Ronald A. Langacker. 1978. Proto-Aztecan Vowels. Parts I, II, III. International Journal of American Linguistics 44:85-102, 197-210, 262-279.

Charney, Jean. 1996. Ute Dictionary. Copy distributed by the author, from the library of William Bright.

Dakin, Karen. 2004. Nahuatl -ka Words: Evidence for a Proto-Uto-Aztecan Derivation. STUF - Sprachtypologie und Universalienforschung/Language Typology and Universals 57:6-22.

Dakin, Karen and Søren Wichmann. 2000 Cacao and Chocolate: A Uto-Aztecan Perspective. Ancient Mesoamerica 11:55-75.

Elliott, Eric Bryant. 1999. Dictionary of Rincón Luiseño. Ph.D. dissertation, University of California, San Diego.

Fowler, Catherine. 1972. Comparative Numic Ethnobiology. Ph.D. dissertation, University of Pittsburgh.

Fowler, Catherine. 1983. Lexical clues to Uto-Aztecan prehistory. International Journal of American Linguistics 49:224-257.

Givón, Talmy. 1979. Ute Dictionary (Preliminary Edition). Ignacio, CO: Ute Press.

Grofe, Michael J. 2006. The Nahua Origin of a Classic Period Maya Deity. Paper presented to the 105th Annual Meeting of the American Anthropological Association, San Jose, CA, November 18, 2006. 


\section{The Proto-Uto-Aztecan Cultivation Hypothesis}

Gudschinsky, Sarah C. 1959. Proto-Popolocan, A Comparative Study of Popolocan and Mixtecan. Indiana University Publications in Anthropology and Linguistics, num. 5. Baltimore, MD: Waverly Press.

Hale, Kenneth L. 1958-59. Internal Diversity in Uto-Aztecan, I-II. International Journal of American Linguistics 24:101-7, 25:114-21.

Hill, Jane H. 2001. Proto-Uto-Aztecan: A Community of Cultivators in Central Mexico? American Anthropologist 103:913-34.

Hill, Jane H. 2003. Proto-Uto-Aztecan Cultivation and the Northern Devolution. In P. Bellwood and C. Renfrew, eds., Examining the Farming/Language Dispersal Hypothesis, 331-40. Cambridge: McDonald Institute for Archaeological Research.

Hill, Jane H. 2006. The historical linguistics of maize cultivation in Mesoamerica and North America. In J. E. Staller, R. H. Tykot, \& B. F. Benz, eds., Histories of Maize: Multidisciplinary Approaches to the Prehistory, Linguistics, Biogeography, Domestication, and Evolution of Maize, 631-47. Amsterdam \& Boston: Elsevier-Academic Press.

Hill, Jane H. 2007. Northern Uto-Aztecan and Kiowa-Tanoan: Evidence of Contact Between the Proto-languages? To appear in International Journal of American Linguistics.

Hill, Jane H. and Kenneth C. Hill. 2004. Word Order Type Change and the Penetration of Spanish de in Modern Nahuatl. STUF - Sprachtypologie und Universalienforschung/Language Typology and Universals 57:23-48.

Huckell, Bruce B. 2005. McEuen Cave and the Origin of Southwestern U.S. Agriculture. Paper presented at the 70th Annual Meeting of the Society for American Archaeology, Salt Lake City, Utah, March 31, 2005.

Huckell, Lisa W. 2005. The Palaeobotanical Record from McEuen Cave, Eastcentral Arizona. Paper presented at the 70th Annual Meeting of the Society for American Archaeology, Salt Lake City, Utah, March 31, 2005.

Kemp, Brian M. 2006. Mesoamerica and Southwest Prehistory, and the Entrance of Humans into the Americas: Mitochondrial DNA Evidence. University of California, Davis Dissertation.

Kaufman, Terry. 1990. Early Otomanguean Homelands and Cultures: Some Premature Hypotheses. University of Pittsburgh Working Papers in Linguistics 1:91-136

Kroskrity, Paul V. 1993. Language, History, and Identity: Ethnolinguistic Studies of the Arizona Tewa. Tucson: University of Arizona Press.

Longacre, Robert E. 1957. Proto-Mixtecan. Indiana University Research Center in Anthropology, Folklore and Linguistics $\mathrm{V}$.

Macri, Martha. 2000. T536 XO From Nahuatl xochitl 'flower'. Glyphdwellers Report 11.

(Electronic document at http://www.ucdavis.edu/NALC/glyphdwellers.html)

Macri, Martha. 2005. Nahua Loanwords from the Early Classic Period: Words for Cacao Preparation on a Rio Azul Ceramic Vessel. Ancient Mesoamerica $16: 321-326$. 
Macri, Martha. 2006 Nahua Loanwords in Proto-Yucatecan. Paper presented to the 105th Annual Meeting of the American Anthropological Association, San Jose, CA, November 18, 2006.

Macri, Martha and Matthew G. Looper. 2003. Nahua in Ancient Mesoamerica: Evidence From Mayan Inscriptions. Ancient Mesoamerica 14:285-297.

Manaster Ramer, Alexis. 2000. Nahuatl (Aztec) Etymologies, I: xīllantli 'womb, belly; flank, side (of the body); chest'; xīlōtl 'tender ear of green maize before it solidifies'; élötl 'a fresh young ear of maize with the kernels already formed, corn on the cob'. Ms. in possession of author.

Miller, Wick R. 1983. Uto-Aztecan Languages. In A. Ortiz, ed., Handbook of North American Indians, Volume 10, Southwest, pp. 113-124. Washington, DC: Smithsonian Institution.

Montes de Oca, Mercedes. 2001. Luiseño Couplets: A Naming Strategy. Paper presented at the Friends of Uto-Aztecan meeting, Santa Barbara, CA, July 9, 2001.

Rensch, Calvin R. 1976. Comparative Otomanguean Phonology. Language Science Monographs Volume 14. Bloomington: Indiana University.

Reséndez, Andrés and Brian Kemp. 2005. Genetics and the History of Latin America. Hispanic American Historical Review 85:283-98.

Robinson, Lila Wistrand and James Armagost. 1990. Comanche Dictionary and Grammar. Dallas, TX: Summer Institute of Linguistics.

Sahagún, Bernardino de. 1981. Florentine Codex, General History of the Things of New Spain. Book 2: The Ceremonies. Arthur J. O. Anderson \& Charles E. Dibble, trs. Santa Fe, NM: The School of American Research and Salt Lake City, UT: The University of Utah.

Smalley, John and Michael Blake. 2003. Sweet Beginnings: Stalk Sugar and the Domestication of Maize. Current Anthropology 44:675-703.

Smith, D. G., J. Lorenz, B. K. Rolfs, R. L. Bettinger, B. Green, J. Eshleman, B. Schultz, and R. Malhi. 2000. Implications of the Distribution of Albumin Naskapi and Albumin Mexico for New World Prehistory. American Journal of Physical Anthropology 111:557-72.

Suárez, Jorge A. 1980. Review of Comparative Otomanguean Phonology (Rensch). International Journal of American Linguistics 46:49-54.

Taube, Karl. 2000. Lightning Celts and Corn Fetishes: The Formative Olmec and the Development of Maize Symbolism in Mesoamerica and the American Southwest. In J. Clark and M. Pye, eds., Olmec Art and Archaeology, 297337. Washington D.C. and New Haven CT: National Gallery of Art/Yale University Press.

Thiel, J. Homer and Jonathan A. Mabry, eds. 2006. Rio Nuevo Archaeology 20002003: Investigations at the San Agustin Mission and Mission Gardens, Tucson Presidio, Tucson Pressed Brick Company, and Clearwater Site. Technical Report No. 2004-11. Tucson, AZ: Desert Archaeology, Inc. 


\section{The Proto-Uto-Aztecan Cultivation Hypothesis}

Vásquez Soto, Verónica. 2001. Cora Clause Structure. Paper presented at the 28th Annual Meeting of the Friends of Uto-Aztecan, Santa Barbara, CA July 8, 2001.

Villavicencio, Frida. 2006. P'orhépecha kaso sïrátahenkwa: Desarrollo del sistema de casos del purépecha. México: CIESAS/El Colegio de México, Ediciones de Casa Chata.

Voegelin, C. F. 1958. Working Dictionary of Tübatulabal. International Journal of American Linguistics 24:221-228.

Wills, W. H. 1995. Archaic Foraging and the Beginning of Food Production in the American Southwest. In T. D. Price and A. B. Gebauer, eds., Last Hunters, First Farmers: New Perspectives on the Prehistoric Transition to Agriculture, 215-242. Santa Fe, New Mexico: School of American Research.

Jane H. Hill

Department of Anthropology

University of Arizona

P.O. Box 210030

Tucson, AZ 85721-0300

jhill@email.arizona.edu 